\title{
Collembolan Communities on the Campus of UOEH and in an Adjacent Natural Forest
}

\author{
Shingo TANAKA ${ }^{1}$ and Yuzo KitAZAWA ${ }^{2}$ \\ ${ }^{1}$ Department of Biology, Faculty of Science, Kyushu University. Fukuoka 812, Japan \\ ${ }^{2}$ Department of Biology, University of Occupational and Environmental Health, Japan. \\ Kitakyushu 807, Japan
}

Abstract: Collembola, one of the representative groups of the soil fauna, was studied in the period from May to July of 1981 at seven minor ecosystems selected along the gradient of human impact in the Kitakyushu area in which the campus of the University of Occupational and Environmental Health, Japan (UOEH) exists. The collembolan fauna included 10 families, 41 genera and 77 species. At the natural forest, the number of species was largest and community diversity and population density were highest. At the secondary forest which remains in the developed area, the number of species were about the same as the natural forest, though the diversity was somewhat higher. They became far less at the shrubbery, the lawn area and or the bare ground with little or no herbs. On the bare ground areas, most of the species belonged to Isotomidae and Onychiuridae, while in the forest, species of Hypogastruridae, Pseudachorutidae and Neanuridae were abundant. The numbers of species and individuals were overwhelmingly high in the uppermost soil layer from 0 to $5 \mathrm{~cm}$ deep at every study site, though there were some species which were distributed in deeper layers in the natural and secondary forests. It was noticeable that the community diversity in both forests was considerably high at the soil layer from 5 to $10 \mathrm{~cm}$ deep. The spacial distribution of the whole Collembola fit the random distribution in the natural and the secondary forests, while that on the lawn and bare ground areas fit strongly clumped distribution. According to the similarity of the specific composition, the collembolan community was divided into three types, i.e. the forest, the herbland and the bare ground type. The fauna of the shrubbery showed an intermediate type between the forest and the herbland.

Key ward: Collembola, human impact, community diversity, spacial distribution, Kitakyushu.

(Received 13 May 1982)

\section{Introduction}

The Collembola or springtails represent one of the most abundant and widespread groups of soil fauna. Their role in the functioning of soil ecosystem was described by HaalфV (1955), Dunger (1956), Wallwork (1970), Kühnelt (1976), Drift \& Jansen (1977) and others, and their significance in zoological soil diagnosis was emphatically discussed by Ghilarov (1965) and Dunger (1968). The present authors studied the faunistic composition, density, spacial distribution, community diversity and similarity of the Collembola at several minor ecosystem types selected along the gradient of human impact in the 
intensively developed Kitakyushu region in relation to the regeneration and maintenance of adequate soil conditions.

\section{Study Sites}

The Kitakyushu area, in which this study was made, is in the warm-temperate broad leaf forest zone. The annual mean temperature is about $15.6^{\circ} \mathrm{C}$ and annual precipitation is about $1700 \mathrm{~mm}$. The soil develops on the palaeogene deposit that contains coal beds. The following seven minor ecosystem types were selected along the gradient of the human impact upon environment for the study of Collembola.

St. A. Natural forest

This station is in a natural evergreen broad leaf forest dominated by Castanopsis sieboldii accompanied with Symplocos glauca. Big trees of C. sieboldii are about 250 years old and more than $100 \mathrm{~cm}$ in diameter at breast height. This forest is regarded as the climax one in this warm-temperate region and this station was selected as a control against other stations which have been disturbed by human agencies in different degrees. This site is on the northern slope of a low hill and about $50 \mathrm{~m}$ in altitude. The top-soil is well developed. The soil type is the typical mesic yellowish brown forest soil and gleization takes place in some places. Thickness of $\mathrm{A}_{0}$ layer was less than $5 \mathrm{~cm}$ in July and that of A layer was 8-14 cm. The amount of leaf fall during a year, from March in 1981 to February in 1982, was estimated at 411 g. d. w. $/ \mathrm{m}^{2}$ by Inagaki (personal communication).

\section{St. B. Secondary forest}

This forest is on a small hill situated on the campus of UOEH. The main constituent deciduous trees are Quercus serrata, Rhus succedanea, Mallotus japonicus and the main evergreen broad leaf trees are Symplocos lucida, Dendropanax trifidus and Lipustrum japonicum. Even the largest trees are less than 30 years in age, less than $10 \mathrm{~m}$ in height and less than $20 \mathrm{~cm}$ in diameter at breast height. The soil type is mesic yellowish brown forest soil. $A_{0}$ layer of the soil was about $4 \mathrm{~cm}$ thick at the time of the study, and A layer was about $8 \mathrm{~cm}$ thick. The amout of leaf fall during a year , from March in 1981 to February in 1982, was estimated at 448 g. d. w. $/ \mathrm{m}^{2}$ by Inagaki, being more than that of the natural forest.

\section{St. C. Shrubbery}

There are many shrubberies on the campus of UOEH. Sampling of Collembola was made in the shrubberies of Eurya emarginata and Rhododendron indicum. The shrubs are trimmed to $40-60 \mathrm{~cm}$ high. They were planted on the new soil brought there one year ago. No marked $A_{0}$ layer is yet formed on the ground surface. 
St. D. Newly formed grassland

The bare ground bulldozed out one year ago on the campus of UOEH has now become a grassland on which grass is growing sparsely. Grass is about $30 \mathrm{~cm}$ high, and bare ground is seen sporadically. Litter layer, less than $1 \mathrm{~cm}$ thick, is formed on the ground surface.

St. E. Lawn area

A study site was chosen at a lawn area on the campus of UOEH. Zoysia japonica about $5-10 \mathrm{~cm}$ high grow thick and fresh $\mathrm{A}_{0}$ layer about $2 \mathrm{~cm}$ thick is formed on the ground surface. The lawn was created one year ago.

St. F. Bare ground and St. G. Bare ground

Two sampling sites were selected on the bare ground areas on the UOEH campus, created by bulldozing out one year ago. St. $\mathrm{F}$ was selected on hard soil containing pebbles and St. G was selected on soft subsoil brought from another place. These two sites are at the earliest stage of the ecosystem succession.

A vegetation study on the campus of UOEH was made by Itow et al. (1981) in which a physiognomic vegetation map is given.

\section{Methods of Sampling and Extraction}

Samplings were made during the period from May 19 to July 2 in 1981.

The size of a soil core was $(4 \times 5 \times 5=100) \mathrm{cm}^{3}$. At Sts. A and $B$ where thick $A_{0}$ layer exsists, $A_{0}$ layer was sampled separating from under layers. Under the $A_{0}$ layer, five soil cores were taken successively to a depth of $25 \mathrm{~cm}$. At St. C, four successive soil cores were taken to a depth of $20 \mathrm{~cm}$, and at Sts. D and E, three soil cores were taken to a depth of $15 \mathrm{~cm}$. At Sts. F and G, only one soil core was taken to a depth of $5 \mathrm{~cm}$. These depths proved to be nearly enough to cover the vertical distribution of Collembola. Sample size was twelve in Sts. A and B, ten in Sts. C-E and eight in Sts. F and G.

Collembola in soil cores were extracted with Tullgren funnels of the separate type by shining with $20 \mathrm{~W}$ electric bulbs for more than 46 hours.

The families, genera and species of extracted Collembola were indentified, and their densities in every soil layer were counted.

\section{Results and Discussion}

1. Faunistic composition

Families, genera and species found at each station are shown in Table 1. The 


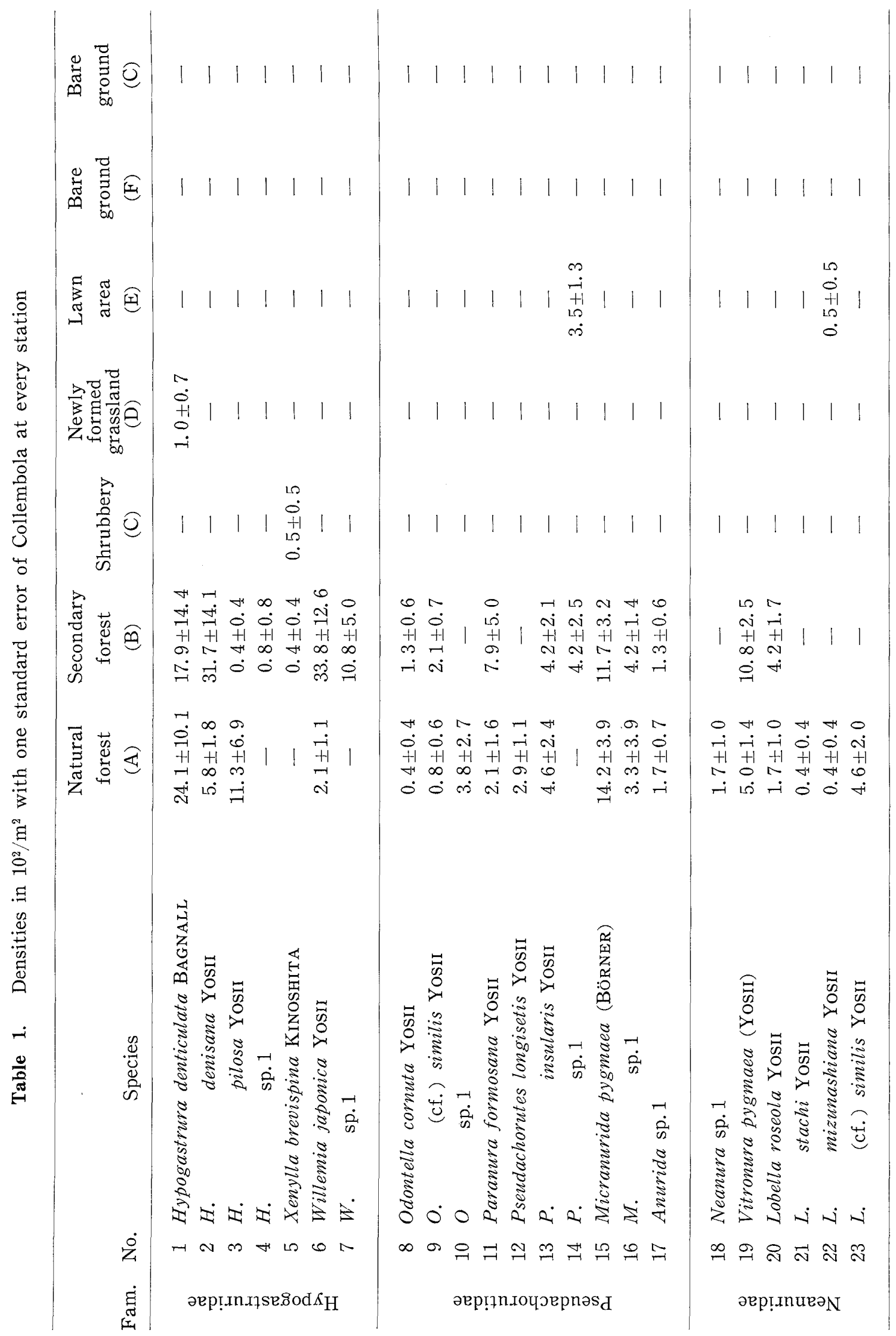


Collembola on the Campus of UOEH

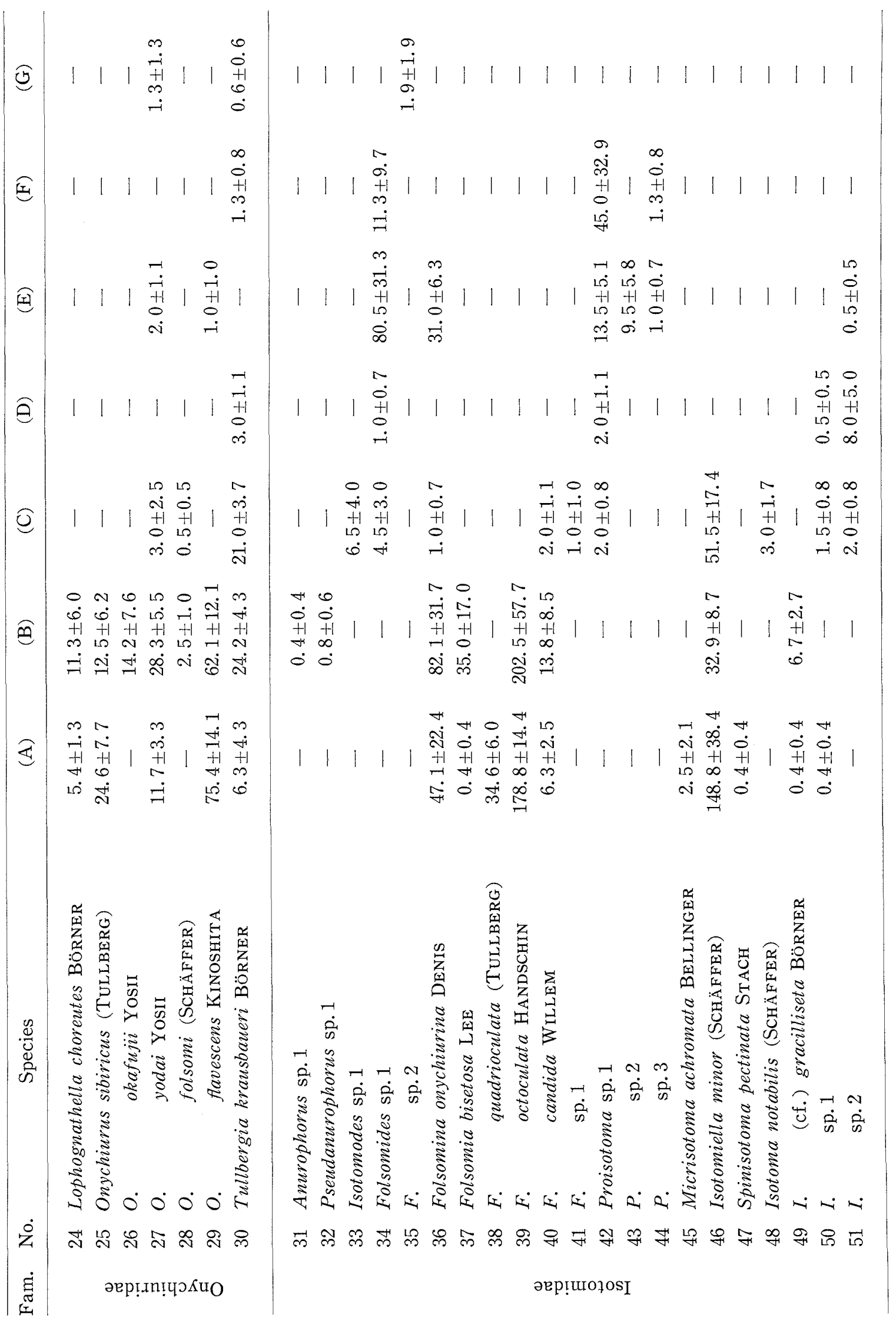




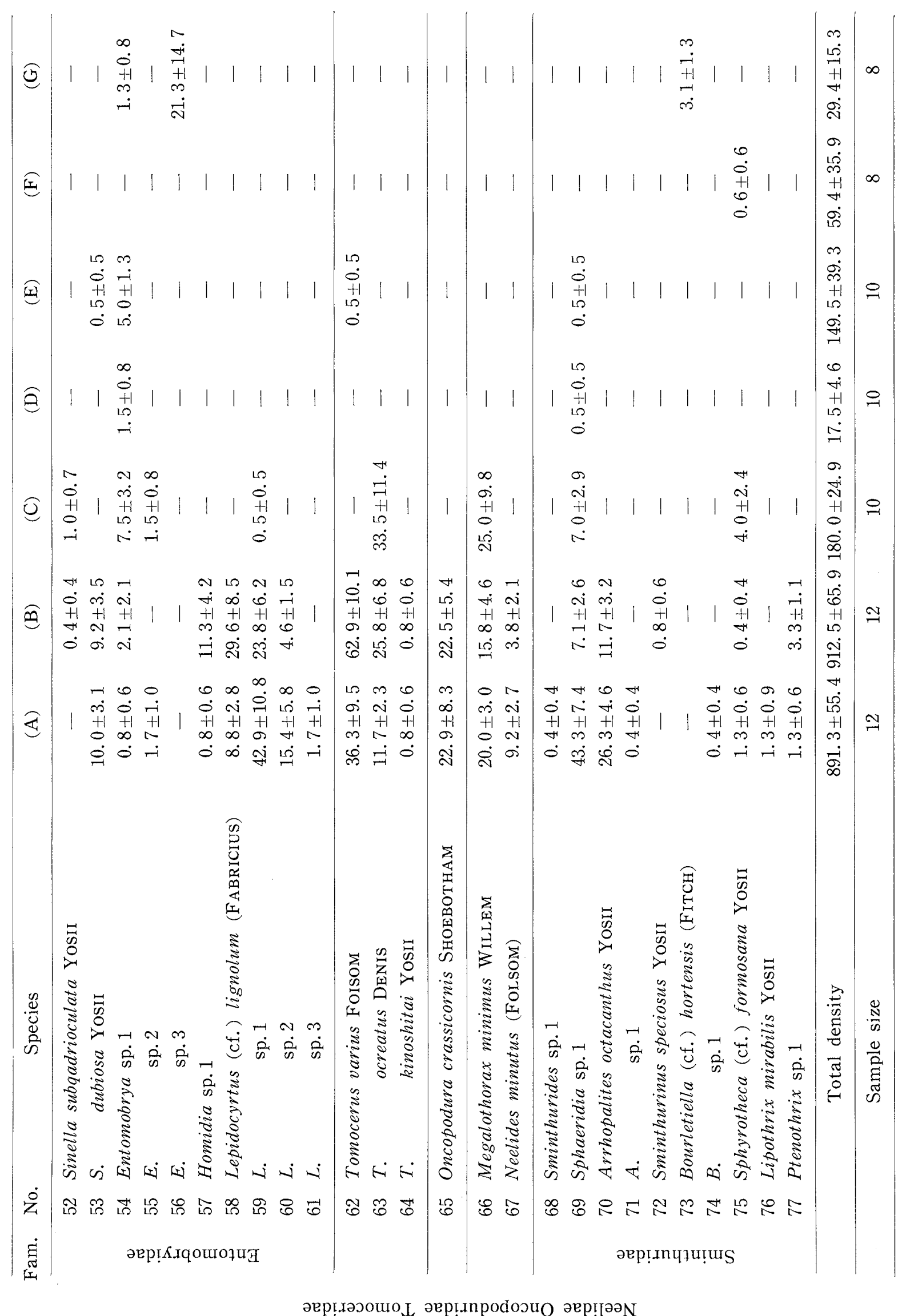


total number of families found at the seven stations is 10 , of genera, 40 and of species, 77. The numbers of species in the forests are large, and it is probable that they would increase considerably if the sample size is increased. They reduce by half at the shrubbery sites and reduce ever more on the bare ground.

Hypogastruridae, Pseudachrutidae, Neanuridae, Oncopoduridae, Neelidae and Tomoceridae are mainly distributed through the forest areas, while Isotomidae and Onychiuridae are distributed through the forests, grassland and bare ground areas. Entomobryidae and Sminthuridae are distributed more evenly through every site. The representative species found in the natural forest are Hypogastrura pilosa and Folsomia quadrioculata; in the secondary forest, Willemia japonica, $W$. sp. 1, Onychiurus okafujii, Folsomia bisetosa and Homidia sp. 1; from the shrubbery Isotomodes sp. 1; from the lawn area Proisotoma sp. 2; and from the bare ground (St. G) Entomobrya sp. 3.

\section{Density}

Densities of Collembola at every station are shown in Table 1 and Fig. 1 . The density of total Collembola in the natural forest is about $90,000 / \mathrm{m}^{2}$. This is rather a large amount in comparison with other data obtained in the evergreen broad leaf forests in Kyushu (Tanaka, 1970; Tanaka et al., 1978). The density in the secondary forest is about the same as that of the natural forest. At the shrubbery area, it is reduced to one-fifth and reduced ever more at the bare ground sites.

The vertical distribution of the density is illustrated in Fig. 2. The mode of vertical distribution at the natural and secondary forests is very similar. About $80 \%$ of the total number was found in the surface soil layer less than five centimeters deep. The

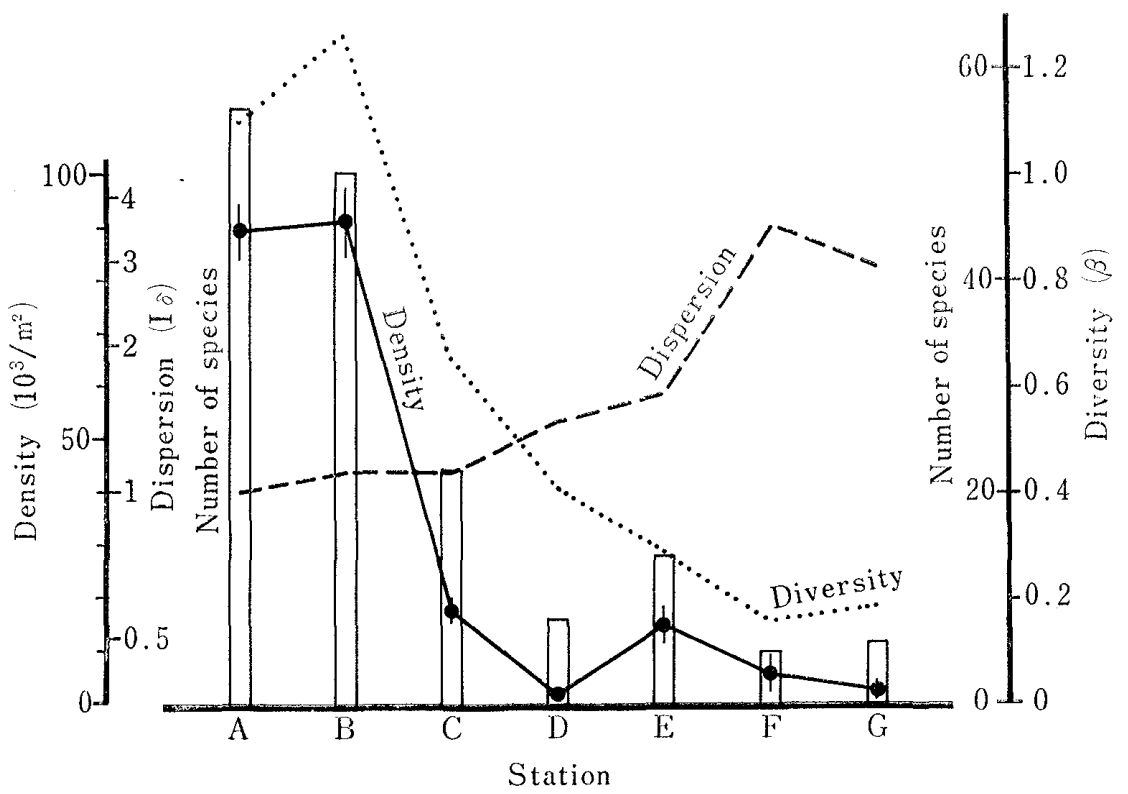

Fig. 1. Total densities, degrees of dispersion, number of species and degrees of community diversity of Collembola at every station. 


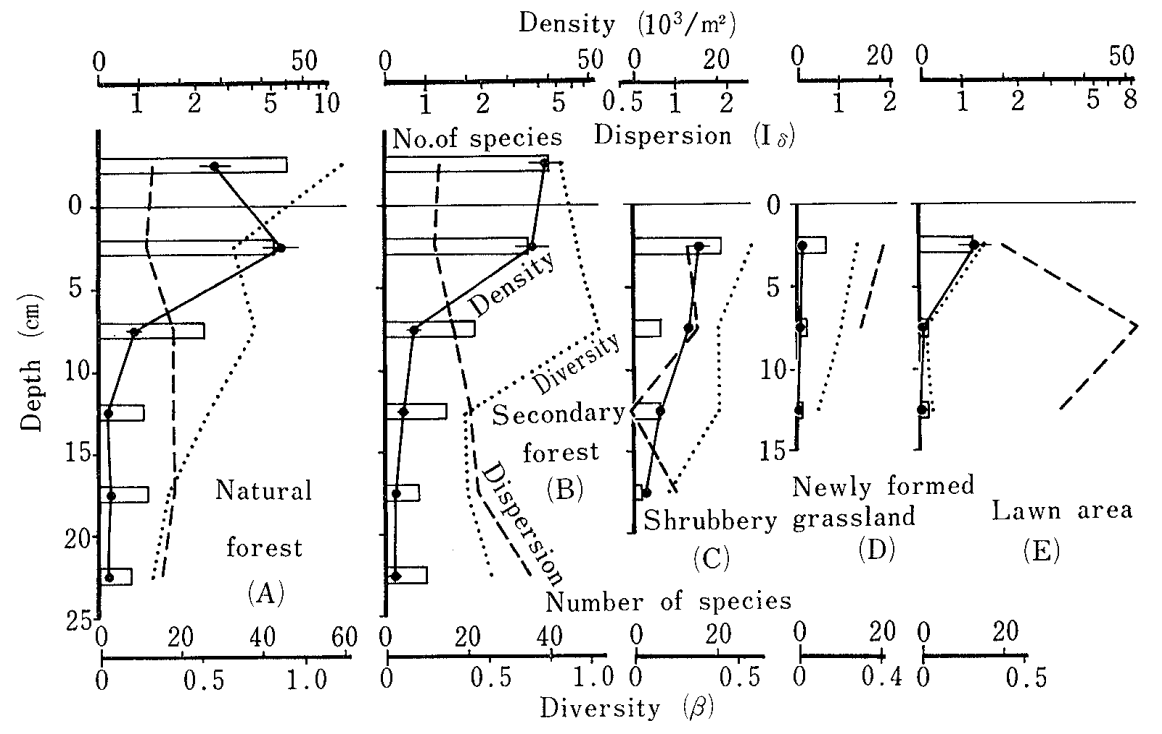

Fig. 2. Vertical changes in densities, degrees of dispersion numbers of species and degrees of community diversity of Collembola at every station.

greater portion of the species that inhabit this layer is not found below $15 \mathrm{~cm}$. At the lawn area and the newly formed grassland, Collembola are very few in the soil layer deeper than $5 \mathrm{~cm}$. The vertical distribution at the shrubbery showed an intermediate type between Sts. A, B and D, E. It is usual that most of the species occur only at the surface layer of the soil, and their population density becomes very low at deeper layers. On the other hand, there are some species which are more abundant at deeper layers, namely, Onychiurus sibiricus, Folsomia quadrioculata and $F$. candida in the natural forest, Willemia japonica, W. sp. 1, Onychiurus sibiricus and Folsomia candida at the secondary forest, and Tullbergia krausbaueri at the newly formed grassland. At other stations no such species were found.

The individual numbers of the majority of the species at the natural and the secondary forests are large, and become near zero at the shrubbery or the newly formed grassland areas. Some species were found mainly or only in the newly formed grassland or the bare ground sites, namely, Tullbergia krausbaueri, Entomobrya sp. 1, rolsomides sp. 1, Proisotoma sp. 1 and Isotoma sp. 1.

\section{Spacial distribution}

It is generally known that the spacial distribution of Collembola is highly clustered (Poole, 1961, 1964; Hale, 1966). The spacial distribution of Collembola at every station was examined by using the $I_{\tilde{b}}$-index given by Morishita (1959a) which is represented as follows,

$$
I_{\delta}=n-\frac{\sum_{i=1}^{n} x_{i}\left(x_{i}-1\right)}{\sum_{i=1}^{n} x_{i}\left(\sum_{i=1}^{n} x_{i}-1\right)}
$$


where $I_{\delta}$ is the index of dispersion, $n$ is the sample size and $x_{i}$ is the individual number in the $i$-th sample. This index is less than unity in a uniform population, and equal to or greater than unity in a random or a clustered population, respectively. Values of $I_{\hat{o}}$ were calculated for total Collembola at every soil layer and at every station. A greater part of the species populations showed clustered distribution. The values of $I_{\delta}$ for total Collembola at every station are shown in Fig. 1 which indicates that total Collembola in the forests (A, B) show random distribution, while those on the newly formed grassland (D) and the lawn area (E) show more clustered distribution and those at the areas of bare ground $(G)$ show highly clustered distribution. These facts are probably related directly to the more even micro-habitat condition of the forests and uneven micro-habitat condition of the newly formed grassland or the bare ground.

The vertical distribution of the value of $I_{\delta}$ is illustrated in Fig. 2. At Sts. A and $\mathrm{B}$, the values of $I_{\hat{o}}$ increase in the deeper soil layers where the population density of Collembola is lower.

\section{Community diversity}

Changes in species diversity of collembolan fauna at every station were studied by using $\beta$-index given by Morishita (1967) which is represented as follows,

$$
\beta=\frac{\sum_{i=1}^{n} x_{i}\left(\sum_{i=1}^{n} x_{i}-1\right)}{\sum_{i=1}^{n} x_{i}\left(x_{i}-1\right)}
$$

where $\beta$ is index of diversity, $x_{i}$ is individual number of the $i$-th species and $n$ is number of species. The more the diversity of the fauna, the more the value of $\beta$ becomes. Thus calculated $\beta$ values at every station are shown in Fig. 1 . The $\beta$ value was the highest at the forest area, and the value in the secondary forest was slightly higher than in the natural forest. It was far lower at the sites other than forests and least at the bare ground areas.

The vertical changes in community diversity are illustrated in Fig. 2. At every station, $\beta$ value reduced at the deeper soil layers, though it was somewhat high at the depth of 5 to $10 \mathrm{~cm}$ at the forest areas.

\section{Faunistic similarity}

The similarity of the species composition of Collembola among every study site was examined firstly by using S\%rensen's coefficient of similarity (S $\dot{m}$ rensen, 1948) which is represented as follows,

$$
\text { Coefficient of similarity }=\frac{2 c}{a+b}
$$

where $a$ and $b$ are numbers of species of the two communities in question, and $c$ is the number of species common to both communities. The calculated values are shown in Table 2. It is indicated that the similarity between the natural and the secondary 
Table 2. Number of species at seven stations and their similarities

\begin{tabular}{|c|c|c|c|c|c|c|c|c|}
\hline \multicolumn{2}{|c|}{ N.P.Sp } & 13 & 7 & 3 & 0 & 1 & 0 & 3 \\
\hline $\begin{array}{l}1 . \mathrm{N} . \\
\mathrm{Sp} .\end{array}$ & St. St. & A & B & $\mathrm{C}$ & D & $\mathrm{E}$ & $\mathrm{F}$ & G \\
\hline 56 & A & & 40 & 13 & 5 & 9 & 1 & 3 \\
\hline 50 & B & .755 & & 14 & 4 & 7 & 1 & 3 \\
\hline 22 & $\mathrm{C}$ & .333 & .389 & 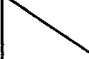 & 7 & 7 & 3 & 3 \\
\hline 8 & $\mathrm{D}$ & .156 & .138 & 467 & 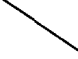 & 5 & 3 & 2 \\
\hline 14 & $E$ & .257 & .219 & 389 & .455 & $\gamma$ & 3 & 2 \\
\hline 5 & $F$ & .033 & .036 & .222 & 462 & .316 & & 1 \\
\hline 6 & G & .097 & .107 & 214 & .286 & .200 & 183 & \\
\hline
\end{tabular}

Note: Total number of species found at each station (T. N. Sp.), number of peculiar species from one station only (N. P. Sp.), values of S $\not$ rensen's coefficient of similarity $\left(\frac{2 \mathrm{c}}{\mathrm{a}+\mathrm{b}}\right)$, and number of species which are common to two stations (N. C. Sp.).

forests is the highest, and considerable degrees of similarity are seen among Sts. C, D, $\mathrm{E}$ and $\mathrm{F}$, while almost no similarity is seen between St. G and other stations.

As Sqrensen's coefficient of similarity does not take the density of the species into account, the index of similarity given by Morishita (1959b) was employed to cover this point. Morishita's index of similarity between two communities is represented as follows,

$$
C_{\lambda}=\frac{2 \sum_{i=1}^{n} x_{1 i} x_{2 i}}{\left(\lambda_{1}+\lambda_{2}\right) \sum_{i=1}^{n} x_{1 i} \cdot \sum_{i=1}^{n} x_{2 i}} \quad, \quad \lambda_{j}=-\frac{\sum_{i=1}^{n} x_{i}\left(x_{i}-1\right)}{\sum_{i=1}^{n} x_{i} \cdot\left(\sum_{i=1}^{n} x_{i}-1\right)}=\frac{1}{\beta_{j}} \quad(j=1,2)
$$

where $C_{\lambda}$ is an index of similarity, $x_{1 i}$ and $x_{2 i}$ are individual numbers of $i$-th species of two communities, and $n$ is number of species.

On the basis of $C_{2}$ values thus calculated, interrelations among similarities of seven collembolan communities were illustrated as shown in Fig. 3. It is indicated that the similarity between the natural and the secondary forests is the highest. From Table 2 it is known that there are as many as 40 species which are common to these two forests. The species composition in the shrubbery is more similar to that in forests than to that at other stations, though there are some species also common to the grasslands (Sts. D and $\mathrm{E}$ ). These things show that the species composition of the shrubbery is of the intermediate type between the forest and the grassland. The species compositions at the 


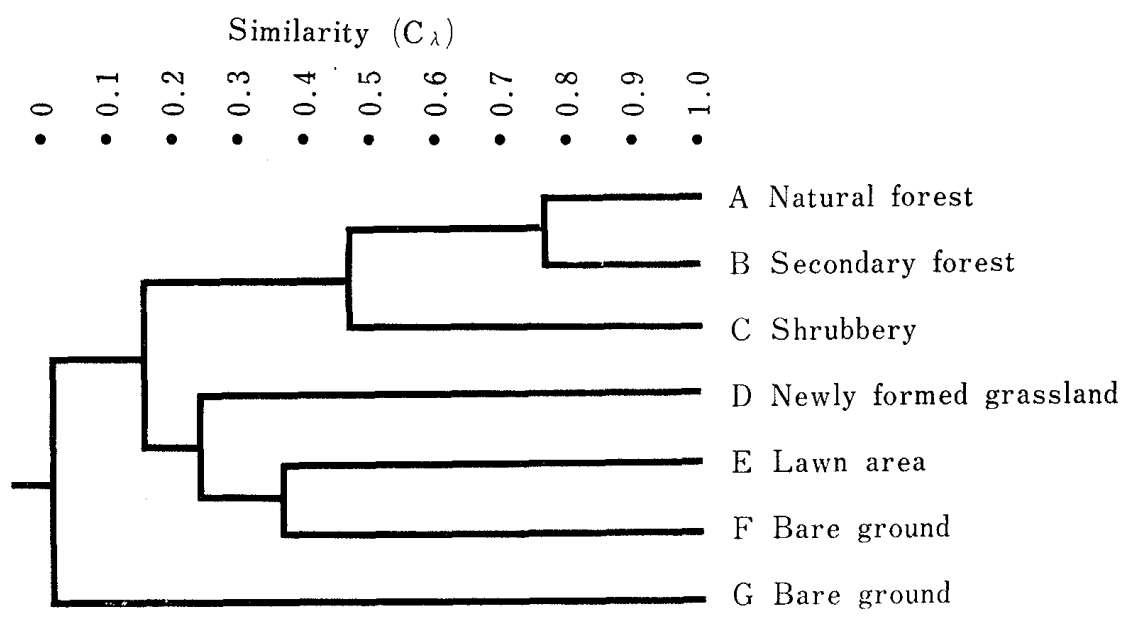

Fig. 3. Interrelation among faunistic similarities of Collembola.

newly formed grassland (St. D), the lawn area (St. E) and the bare ground (St. F) are similar though with not so high degree. This similarity is caused by the fact that there are some predominating species which are common to these three stations, such as Folsomides sp. 1 and Proisotoma sp. 1. These species are representative ones of the grassland areas. Many of the species at the St. F, one of the two bare ground stations, are common to those of St. D and St. E, which would be due to the invasion of Collembola from neighboring grasslands. The similarity of St. $G$ to other stations is extremely low. The diversity of the collembolan community of the bare ground is generally low and the spacial distribution is highly clustered. The collembolan community of the bare ground areas is influenced easily even by small differences in environmental conditions in or outside of the area.

This study was supported by Grant-in-Aid No. 56030078 in 1981 for Special Research Project on Environmental Science, Ministry of Education, Culture and Science, Japan.

\section{References}

Drift, J. van der \& Jansen, E. (1977): Grazing of springtails on hyphal mats and its influence on fungal growth and respiration. In: Soil Organisms as Components of Ecosystems. (Lohm, U. \& Persson, T., ed.). Ecological Bulletin, 25. Liber Tryck, Stockholm. pp. 203-209.

Dunger, W. (1956): Untersuchungen über Laubstreuzersetzung durch Collembola. Zoologische Jahrbücher Abt. Syst. Ökol. Geogr. Tiere, 84: 75-98.

Dunger, W. (1968): Die Entwicklung der Bodenfauna auf rekultivierten Kippen und Halden des Braunkohlentagebaues. Ein Beitrag zur pedozoologisches Standortsdiagnose. Abhandl. Ber. Naturkundemuseums Görlitz, 43 (2): 1-256.

Ghilarov, M.S. (1965): Zoological Methods in Soil Diagnosis. Nauka, Moscow. 278 pp. (in Russian with English summary).

Haal $\phi v$, N. (1955): Vertical distribution of mites and Collembola in relation to soil structure. In: Soil Zoology. (Kevan, D. K. McE., ed.) Butterworths Sci. Pub., London. pp. 167-179. 
Hale, W. G. (1966): A population study of moorland Collembola. Pedobiologia, 6: 65-99.

Itow, S., Jinno, N., Kitazawa, Y. et al. (1981): Vegetation of the UOEH campus and its vicinities with reference to conservation of campus environment. J. UOEH, 3: 323-337.

Kühnelt, W. (1976): Soil Biology with Special Reference to the Animal Kingdom. Faber and Faber, London. 483 pp.

Morishita, M. (1959a): Measuring of the dispersion of individuals and analysis of the distributional pattern. Mem. Fac. Sci., Kyushu Univ., Ser. E. (Biol.), 2: 215-235.

Morishita, M. (1959b): Measuring of interspecific association and similarity between communities. Mem. Fac. Sci., Kyushu Univ., Ser. E. (Biol.), 3: 65-80.

Morishita, M. (1964:) Application of $\mathrm{I}_{\hat{\delta}}$-index to sampling techniques. Res. Popul. Ecol., 6: 43-53.

Morishita, M. (1967): The seasonal fluctuation of butterfly nearby Kyoto. In: Nature-Ecological Study. (Morishita, M., \& Kira, T., ed.) Chuo-Koron-Sha, Tokyo. pp. 95-132. (in Japanese).

Poole, T.B. (1961): An ecological study of the Collembola in a coniferous forest soil. Pedobiologia, 1: $113-137$.

Poole, T.B. (1964): Study of the distribution of soil Collembola in three small areas in a coniferous woodland. Pedobiologia, 4: 35-42.

S $\phi$ rensen, T. (1948): A method of establishing groups of equal amplitude in plant sociology based on similarity of species content and its application to analyses of the vegetation on Danish commons. Biol. Skar. (K. danske vidensk. Selsk. N. S. ), 5: 1-34.

Tanaka, M. (1970): The bio-economics of the populations of Isotoma (Desoria) trispinata MAGGILLIVRAY (Collembola: Isotomidae) and Onychiurus (Protaphorura) sp. (Collembola: Onychiuridae) in a grassfield. Publ. Amakusa Mar. Biol. Lab. Kyushu Univ., 2: 51-120.

Tanaka, M., Sugi, Y., Tanaka, S. et al. (1978): Soil invertebrates. In: Biological Production in a Warm-Temperate Evergreen Oak Forest ofJapan. (Kira, T., Ono, Y. \& Hosokawa, T., ed.) JIBP Synthesis, 18. Univ. Tokyo Press, Tokyo. pp. 147-163.

Wallwork, J.A. (1970): Collembola. In: Ecology of Soil Animals. McGraw-Hill, London. pp. $130-149$.

産業医科大学構内と付近の自然林のトビムシ類群集の比較研究

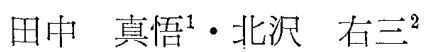

九州大学理学部生物学教堂 2 産業区科大学生物学教堂

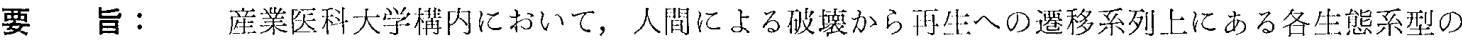
代表として，2 ケ所の新造成裸地，芝生，新生啅地，植込，二炏林を選び，刘照として北 九州地域の生態系僄移の極相を示す常緑広葉樹の自然林を扣えた，合計 7 ケ所の土裹乎の トビムシ（昆虫網，粈管目）在比較研究した。自然林のトビムシは密度，種数，多様度と も高く、三次林はこれに匹敵するかまたはより惉いほどであった。これらは植込から裸地 にかけて徐々に低下したが，密度と種数は新生草地で著しく落ち达んだ．密度の重直変化

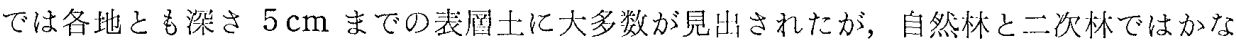
り深い所まで分布する種もあった。他の新造成諸地点のうち，真砂土を客士してつくられ

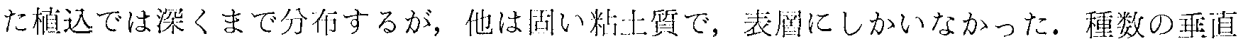
変化もほぼ同様であった。全卜ビムシの分们型は森林でランダム分存を示し，芝生から絽 地にかけて徐々に強い集中分死となっていた，各地の群集はその組成の類似度から，箖林 
型 (自然林之二次林), 草地型 (新生草地と芝生), 裸地型に分けられる. 植込は森林と草 地の中間型で, 裸地は周团の影響を受けるとともあるが, 特有な群集を形成する傾问があ る.

J. UOEH（産業医大誌)，4 ( 3$) ： 313-325$ (1982) 